\title{
CURRENT ISSUES OF THE CORRECTION AND RESOCIALIZATION PROCESS OF CONVICTED SERVICEMEMBERS
}

\author{
АКТУАЛЬНІ ПИТАННЯ ПРОЦЕСУ ВИПРАВЛЕННЯ І РЕСОЦАЛЛЗАЦІЇ \\ ЗАСУДЖЕНИХ ВІЙСЬКОВОСЛУЖБОВЦІВ
}

\author{
Tsariuk S.V., Candidate of Law, \\ Associate Professor at the Department of Criminal, Criminal-Executive Law and Criminology \\ Academy of the State Penitentiary Service \\ Nesterenko V.V., Postgraduate Student at the Faculty of Law \\ Academy of the State Penitentiary Service
}

\begin{abstract}
The article is devoted to the current state of war crime, as well as analyzes the correctional measures of the Armed Forces of Ukraine and a range of issues related to the process of correction and resocialization of convicted servicemembers. An urgent issue that is currently on the agenda of certain scholars is the development and implementation of effective means and methods of correction of convicted servicemembers. A thorough analysis of military crimes from the pre-war period of 2014 to the present gives us a basis for finding more effective mechanisms to influence the military and highlight the legislative changes needed to improve the functioning of the law enforcement system. The article considered that while ensuring the correction and resocialization of convicted servicemembers, it is necessary to take into consideration the criminological portrait of a military offender. Separately, attention was paid to mobilized military who went far beyond the frames of typical staff of the Armed Forces of Ukraine. Having well verified the legislative changes caused by Ukraine's movement towards NATO membership, it becomes clear that the quantitative and qualitative transformation of the personnel of the Armed Forces of Ukraine necessitates on the search for effective ways to satisfy the needs of convicted servicemembers during corrective and resocialization measures. Taking into account the specificity of such subjects of criminal offenses, and the rapid development of the Armed Forces of Ukraine, as a structure which is in the process of reformation and in active state of undeclared war with the Russian Federation, we proposed measures to correct and resocialize convicted servicemembers, which certainly would ensure the protection of their rights and interests, as well as helped them to format a mechanisms of legal socialization and law-abiding behavior in their personalities.

Key words: servicemember, criminal offenses, military crime, punishment, correction, disciplinary influence.
\end{abstract}

Стаття присвячена висвітленню сучасного стану військової злочинності, а також проаналізовано виховну діяльність Збройних сил України та коло питань, пов'язаних із процесом виправлення і ресоціалізації засуджених військовослужбовців. Актуальне питання, що зараз стоїть на порядку денному в кола науковців, - це розробка і впровадження дієвих засобів та методів виправлення засуджених військовослужбовців. Грунтовний аналіз військових кримінальних правопорушень, починаючи з довоєнного періоду 2014 року та закінчуючи сьогоденням, дає нам підґрунтя для пошуку більш дієвих механізмів впливу на військовослужбовців та виокремлення законодавчих змін, необхідних для покращення функціонування системи правоохоронних органів загалом. У статті було зважено на те, що під час забезпечення виправлення і ресоціалізації засуджених військовослужбовців необхідно приділяти більше уваги кримінологічному портрету військового злочинця. Окремо була приділена увага мобілізованим військовослужбовцям, які виходили далеко за рамки примірного рядового або начальницького складу Збройних сил України. Добре вивіривши законодавчі зміни, що зумовлені рухом України до членства в НАТО, нам стає зрозуміло, що кількісне і якісне перетворення особового складу Збройних сил України викликає необхідність пошуку дієвих шляхів урегулювання потреб військовослужбовців під час застосування до них заходів виправлення і ресоціалізації. Беручи до уваги специфічність даних суб'єктів кримінальних правопорушень, а також швидкий розвиток Збройних сил України як структури, що перебуває у процесі реформування та стані неоголошеної війни з Російською Федерацією, нами були запропоновані заходи виправлення і ресоціалізації засуджених військовослужбовців, що неодмінно задовольняли б потреби самих військовослужбовців та забезпечили б захист їхніх прав та інтересів, а також сприяли формуванню в їхній особистості механізмів правової соціалізації та правослухняної поведінки.

Ключові слова: військовослужбовці, кримінальні правопорушення, військові злочини, покарання, виправлення, дисциплінарний вплив.

Military service is a unique public service of a special nature that provides people with a variety of opportunities that are not usually available in a civilian environment. If we consider the Armed Forces of Ukraine (hereinafter - the Armed Forces) as an employer, then undoubtedly, the military service mostly attracts young men and (recently women) who are imbued with the spirit of patriotism, desire to protect their homeland, and want to improve their financial situation and receive benefits, such as free education, medical care and others [1].

We want to pay attention to other factors in choosing the profession of a servicemembers, as military service is an attractive alternative for people who eager to commite offences. Some researchers argue that military service legitimizes the violent inclinations of some individuals, and therefore the relevance of the study of ways to refrain servicemembers from such actions and analysis of the main areas of disciplinary influence on servicemen will be the scope of this article.

The issue of researching the crime of servicemembers has been considered by scientists mostly from the standpoint of identifying the determinants of committing criminal offenses during military service or prosecution as a consequence of such actions. However, the issue of legal regulation of the process of their correction and application of the basic means of disciplinary influence to them were left out of their attention.

Noting the authors who covered certain issues, we can mention such leading native and foreign scientists such as: M. Brown, I. Bogatyrev, A. Galay, M. Kolodyazhny, J. Kulkina, K. Muravyov, A. Onyskiv, I. Panov, D. Segal, Y. Sokorinsky, S. Kharitonov, I. Yakovets and others.

At the same time, modern law enforcement practice is based on such reforms in the combat against crime such as: "Concept of reformation (development) of the penitentiary system of Ukraine" and "Strategy for reforming the judicature, judiciary and related legal institutions for 2015-2020", as well as pursuant to "Recommendation CM / Rec (2014) 4" adopted by the Committee of Ministers of the Council of Europe on February 19, 2014 expands the list of alternatives to imprisonment by amending the current legislation, which is clearly seen in the latest version of the Criminal Code of Ukraine [2]. Their analysis leads to the conclusion that Ukraine is moving towards improving its legal framework and bringing it into line with NATO standards, which is carried out comprehensively and in various ministries of Ukraine. For example, the "Annual National Program under the auspices of the NATO-Ukraine Commission for 2020" has already results $[3 ; 4]$, and therefore the relevance of the material 
and conclusions presented in this article will certainly be useful for scientists and practitioners involved in programs of defense and legal reforms.

The purpose of the scientific article is to study and determine some patterns of criminal offenses during military service in Ukraine, as well as to study the current state of disciplinary impact of means of correction applied to the offender of the established rules of military service.

It should be noted that previous studies have not taken into account the recruitment of women for military service, which is one of the shortcomings in the study of this topic, as the number of women who have signed a contract for military service over the past 5 years has increased 15 times. This was facilitated by the adoption of the Law "On Amendments to Certain Laws of Ukraine on Ensuring Equal Rights and Opportunities for Women and Men during Military Service in the Armed Forces of Ukraine and Other Military Formations" of September 6, 2018 № 2523-VIII, and now their number is more than 55 thousand [5]. Our analysis of this legal act shows that the process of enlistment in the military service has not changed significantly and contains general rules for both men and women, except for marital status, where marriage and children affect the military service of women. Regarding the quantitative indicators of crime among servicemembers, we cannot assume that women will commit less crimes than men, however, we note that in our opinion, measures of correction and resocialization in case of conviction of women should take into account their gender characteristics.

The issue of committing military crimes in 2014-2016 has been repeatedly considered by scientists, such as: T. Kasko, E. Kovalevskaya, A. Mukhamedzhanova, A. Onyskiv, S. Dyachuk, M. Karpenko, and others, and therefore the increase in the number of military crimes in those years is justified in their works [6]. On the other hand, studying the patterns of crimes committed during military service in Ukraine, we want to note that in 2017 the state of military crime did not differ much from 2016, but in 2018 it decreased and the number of criminal offenses began to setback, as the mobilized servicemembers were demobilized and there were no "accidental" people left in the army. See (fig. 1).

The staff of the Armed Forces of 2018-2019 differs from 2014 not only quantitatively but also qualitatively, which led to a change in the criminological portrait of a military criminal, making this category typical for more mature people. In our opinion, this was facilitated by the Decrees of the President of Ukraine, according to which he signed annually from 2014 to 2019 a call-up for military service of males who were 20 years old till they were sent to military units, but who did not reach 27 years or have the right to exemption or deferment of conscription, a significant increase in salaries for servicemembers by Order № 260 “On approval of the Procedure for payment of cash benefits to servicemen of the Armed Forces of Ukraine and certain other persons" from 07.06.2018 [7], as well as Law № 2523-VIII "On Amendments to Certain Laws of Ukraine on Ensuring Equal Rights and Opportunities for Women and Men During Military Service in the Armed Forces of Ukraine and Other Military Formations", which became valid on October 27, 2018. Thus, more adult and experienced soldiers, as well as women, began to join the Armed Forces, which, in our opinion, suspended and stabilized the level of crime in the Armed Forces.

Having studied the reports of the Prosecutor General Office of Ukraine on persons who committed criminal offenses in 2018-2019 [8] and the results of a study by individual scientists (P. Bannet, K. MacDonald, M. Puzyrev and others) on the criminological characteristics of persons who committed military crimes, we came to the conclusion that the conscription age (18-24 years) accounted for the transition to adulthood,

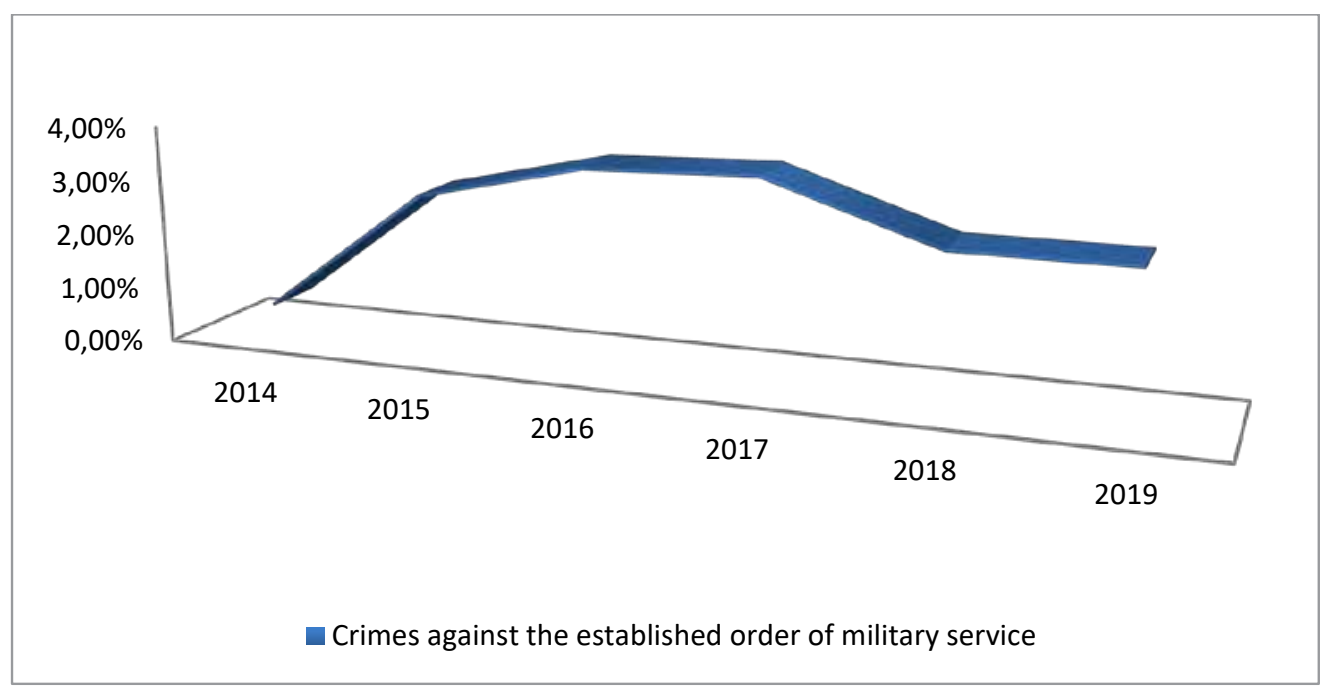

Fig. 1. Graph of quantitative indicators of military crime (2014-2019)

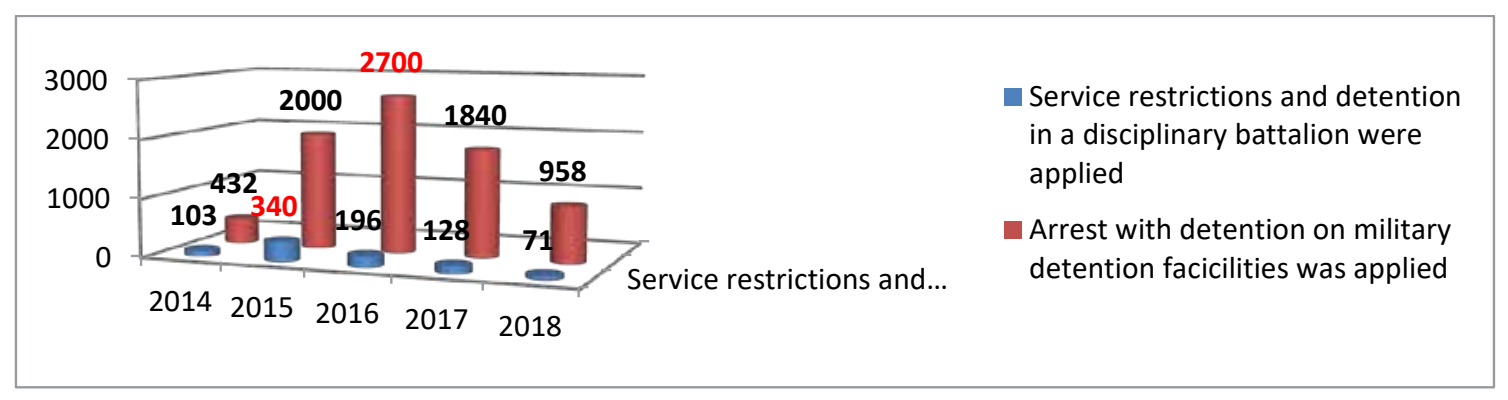

Fig. 2. Comparative histogram of application of different types of punishments to servicemembers of 2014-2018 
is interconnected with the committing thoughtless and hasty actions of an illegal nature. This is confirmed by the results of a study by S. Yakimova, where $37 \%$ of all criminal offenses are committed at this age [9]. Based on the data of judicial statistics for 2014-2018 (see Fig. 2) and examination of the disciplinary practice and judicial statistics of 2018-2019, we note that such a change as increasing the average age of military criminals has positive consequences to this day [10].

According to the latest amendments made by Presidential Decree № 13/2020 “'On dismissal of conscripts, terms of regular conscription and regular conscription of Ukrainian citizens for military service in 2020" of 16.01.2020, the conscription of young men from 18 years was brought back [11]. This Decree will certainly make its adjustments to the criminalexecutive characteristics of a military criminal in the future.

We will also pay attention to the international experience of studying the problems related to military crime, as a comparative analysis of conceptual approaches to combating this negative phenomenon will allow us to find the right ways to solve this problem. Foreign researchers and available statistics show that most servicemembers who have committed a crime need psychological help, and before starting corrective work with them, it is necessary to clarify the preconditions for committing this criminal offense, and determine the state of mental health, because any means of correction and resocialization will not make sense when the servicemember is concerned about other problems and issues. For example, it is not advisable to conduct with the convict general corrective measures (social and disciplinary work) or special corrective measures (military training classes) when he barely survived the enemy mortar shelling, or he has recently witnessed the death of his fellow [12].

In case of a real criminal liability and validness of a court conviction against a servicemember, at the stage of execution of the sentence, we consider it primarily appropriate to use psychological assistance, and therefore, in our opinion, it would be appropriate to develop a provision setting out algorithms for psychological assistance and create Department of Rehabilitation Psychology at military units, military detention facicilities and structural subdivisions of the Military Law Enforcement Service of the Ministry of Defense of Ukraine, where it would be possible to establish contact with military offenders and satisfy their psychoemotional needs, the solution of which would be part of their resocialization

Another factor that affects the effectiveness of correction, in our opinion, is the loss of social ties that the offender had before joining the Armed Forces, and consequently those that he lost after committing a criminal offense. Both of these losses must be taken into account both after and before the verdict in court. We believe that it would be correct to provide permanent social support measures towards servicemembers aged 18-24, which would be focused on helping newcomers. During these activities, motivational work, professional training and constant encouragement of young servicemembers in self-improvement should be carried out. It is necessary to organize the service so that the servicemember, having entered the service, would not be left alone with his problems, but would work and develop in the direction of their solution.
Based on the life circumstances of the military, measures may be the following: free acquisition of an additional profession; obtaining a driver's license; additional exemptions from the location of the military unit (for conscripts). It may also occur during the execution of a court sentence, placement on military detention facicilities or service restrictions for servicemembers, it is necessary to give a person a goal that will stimulate and help him choose the means of its implementation.

Returning to the increase in the number of women in the military, we note that in the criminal world, women do not play an important role, so they tend to commit less dangerous crimes, receive less severe punishments and are more likely to be amnestied than men, however, speaking of women servicemen, modern Ukrainian legislation seeks to ensure gender equality. In conclusion, we would like to emphasize that the practice of gender equality in criminal prosecution exists in many leading countries of the world, such as: France, the USA, Israel [13, p. 515-517].

Having analysed the indicators of the state of military crime for the last five years, we can state that the Armed Forces in 2014-2017 had ineffective mechanisms to curb the growth of military crime, but, nevertheless, since 2018 it has managed to slow down and reduce growth. Although the reforms of 2016 2020 have yielded positive results, it is still not possible to reduce the state of military crimes. After analyzing the trends and current state of legislation which regulate the rights, duties and responsibilities of servicemember $\mathrm{s}$ who violated the established rules of military service, we determined that both the legislative and practical component of the appointment and application of corrective and resocialization measures is being developed, and, therefore, our ideas on psychological support and support of social ties, developed on the basis of the analyzed modern Ukrainian and foreign experience will be reflected in practical application. Firstly, the issue of age orientation in the selection of measures applied to servicemembers should be developed taking into account a possible military mobilization order. Secondly, in our opinion, a clear system of social rehabilitation of convicts is needed, which would function in the military sector. This needs to be resolved by implementing the "Department of Social Rehabilitation of Military Offenders" into the structure of military units and departments of the Military Law Enforcement Service. Thirdly, we suggest to decide the issue of harmonization of regulations on the application of punishment to women servicemen. As the gender structure of the Armed Forces personnel has changed since 2018, the bodies that ensure law and order among servicemembers also need to be changed accordingly. In our opinion, it would be expedient to amend the current Order "On approval of the Instruction on the organization of regular shifts of protection and convoying units of the Military Law Enforcement Service in the Armed Forces of Ukraine and escorting convicts, detainees, arrested and detained servicemembers” № 20 of 22.01.2018 supplementing Section II "Regular changes of guard and convoy" part 1, item 2 with the following paragraph: "The assistant chief of the regular shift of guard and convoy, a female serviceman, with the right to perform the duties of a withdrawal officer, shall be appointed to the regular shift of guard and convoy".

\section{REFERENCES}

1. Про соціальний і правовий захист військовослужбовців та членів їх сімей : Закон України від 20 грудня 1991 р. № 2011-XII. URL: https://zakon.rada.gov.ua/laws/show/2011-12\#Text (дата звернення: 25.09.2020)

2. Кримінальний кодекс України : Закон України від 5 квітня 2001 р. № 2341-III. URL: https://zakon.rada.gov.ua/laws/show/2341-14\#Text (дата звернення: 25.09.2020)

3. Мін'юст прийняв наказ «Про затвердження змін до деяких нормативно-правових актів Міністерства юстиції України щодо поліпшення умов тримання засуджених та осіб, узятих під варту» від 28 вересня 2020 р. Міністерство юстиції України : офіційний вебсайт. URL: https://minjust.gov.ua/news/ministry/minyust-priynyav-nakaz-pro-zatverdjennya-zmin-do-deyakih-normativno-pravovih-aktiv-ministerstvayustitsii-ukraini-schodo-polipshennya-umov-trimannya-zasudjenih-ta-osib-uzyatih-pid-vartu-28837 (дата звернення: 25.09.2020).

4. Запровадження стандартів та інших керівних документів НАТО: Міністерство оборони України : офіційний вебсайт. URL: https://www.mil.gov.ua/diyalnist/vprovadzhennya-standartiv-ta-inshih-kerivnih-dokumentiv-nato.html (дата звернення: 25.09.2020). 
5. Полтавець Т. «Наша сила - у нашій слабкості» : Закон про ґендерну рівність чоловіків та жінок у Збройних силах України. Громадська думка про правотворення. Київ, 2018. Вип. № 16 (160). С. 10-12.

6. Злочини проти встановленого порядку несення військової служби (військові злочини) : теоретичні та прикладні аспекти : монографрія / М. Карпенко ; за заг. ред. В. Матвійчука. Київ : ВНЗ «Національна академія управління», 2018. 420 с.

7. Про затвердження Порядку виплати грошового забезпечення військовослужбовцям Збройних Сил України та деяким іншим особам : наказ Міністерства оборони України від 7 червня 2018 р. № 260. URL: https://zakon.rada.gov.ua/laws/show/z0745-18\#Text (дата звернення: 28.09.2020).

8. Про осіб, які вчинили кримінальні правопорушення (за даними судової статистики). URL: https://old.gp.gov.ua/ua/stst2011.html?dir_ id=113898\&libid=100820\&c=edit\&_c=fo (дата звернення: 29.09.2020).

9. Якимова С. Кримінологічний портрет особистості насильницького злочинця, який учиняє злочини з мотивів задоволення статевої пристрасті. Вісник Національного університету «Львівська політехніка». Серія «Юридичні науки». Львів. 2014. № 810 (2014). С. $220-225$.

10. Судова статистика у 2014-2018 pр. (за даними судової статистики). URL: https://court.gov.ua/inshe/sudova_statystyka/ (дата звернення: 29.09.2020).

11. Про звільнення в запас військовослужбовців строкової служби, строки проведення чергових призовів та чергові призови громадян України на строкову військову службу у 2020 р. : Указ Президента України від 16 січня 2020 р. № 13/2020. Офріс Президента України. URL: https://www.president.gov.ua/documents/132020-31825 (дата звернення: 30.09.2020).

12. Herbert B. The Way We Treat Our Troops. The New York Times. 2010. URL: https://www.nytimes.com/2010/10/23/opinion/23herbert. html?auth=linked-google (дата звернення: 30.09.2020).

13. The Naval Officer's Guide. Annapolis, 1983. P. 515-517. 